\title{
Perbedaan Religulasi Emosi dan Jenis Kelamin pada Mahasiswa yang Bersuku Batak dan Jawa
}

\author{
Widiean Gabriele Yolanda \\ Y. Bagus Wismanto \\ Email : gabrieleyolanda@gmail.com \\ Fakultas Psikologi \\ Universitas Katolik Soegijapranata, Semarang
}

\begin{abstract}
This study aims to determine differences of emotion regulation and sex in the Batak ethnic students and Javanese ethnic students. Sampling was conducted using accidental quota sampling. Total subjects in this study were 120 people comprising 60 Batak ethnic students and 60 Javanese ethnic students. Data collection is done by using the scale of emotional regulation in validity test and valid. Data were analyzed using Independent Sample Test. The results show that the difference between the emotion regulation and the Batak ethnic student of Javanese ethnic is significant with results $t_{o}=-2.355$ and $p<0,05$. Then the results analysis of emotion regulation between men and women is not significant. This shows that there are differences in emotion regulation in students who have Batak ethnic and Javanese ethnic. The level of emotion regulation Javanese ethnic of students better than students that of the Batak ethnic students. In sex, as a whole showed no differences in emotion regulation between women and men, emotion regulation means women no higher than men.
\end{abstract}

Keywords: emotion regulation, sex, Batak ethnic and Javanese ethnic. 


\section{PENDAHULUAN}

Emosi memegang peranan penting dalam kehidupan manusia. Dalam kehidupan sehari-hari, emosi akan mengalami perkembangan dan proses kematangan. Proses pencapaiannya sangat dipengaruhi oleh kondisi emosional individu. Manusia dengan adanya emosi, memberinya identitas dan belajar dari segala perubahan perasaan yang memengaruhi perilaku. Bagaimana individu mendefinisikan emosi, seberapa penting individu memandangnya, bagaimana individu mengelolanya, merasakannya, menerimanya dan mengekspresikannya.

Regulasi emosi (Gross, 2007) ialah strategi yang dilakukan secara sadar ataupun tidak sadar untuk mempertahankan, memperkuat atau mengurangi satu atau lebih aspek dari respon emosi yaitu pengalaman emosi dan perilaku. Kemampuan individu dalam meregulasi emosi menjadi salah satu kekuatan dalam menghadapi lingkungan dan membuat individu merasa diterima secara sosial. Regulasi emosi yang dimaksud fokus pada kemampuan individu dalam penyesuaian diri mengatur dan mengekspresikan emosi dan perasaan dalam kehidupan sehari-hari melalui sikap dan perilakunya, seperti proses dalam beradaptasi dan merespon terhadap lingkungan sosial disekitarnya.

Fenomena yang terjadi akibat kurangnya regulasi emosi yaitu kasus kekerasan banyak terjadi di Indonesia, seperti kasus cyberbullying di tahun 2010 (Rifauddin, 2016) antar teman sebaya melakukan penghinaan melalui situs jejaring sosial facebook; Kekerasan antar orang tua dan anak di Jakarta Utara pada tahun 2006 (Suara Merdeka, 2016) seorang anak disetrika oleh ayahnya karena kedapatan menyimpan uang seratus ribu rupiah. Kekerasan yang berhubungan dengan perbedaan suku (Natalia, 2015) yaitu konflik Sampit pada tahun 2001, Papua tahun 2012 dan 2014, konflik Lampung tahun 2012, konflik Flores dan konflik Sigi.

Faktor-faktor yang dianggap secara teoritis memengaruhi regulasi emosi terdapat dua bentuk baik secara intrinsik maupun ekstrinsik diantaranya yaitu usia, kognitif, kepribadian, seks, jenis kelamin, spiritual, keluarga, lingkungan sosial dan budaya (Gross, 2007); (Strongman, 2003). Dalam hal ini peneliti mengambil budaya dan jenis kelamin.

Menurut Slovey dan Sluyter (Nisfiannoor \& Kartika , 2004) emosi antara perempuan dan laki-laki bergantung pada peran yang ada di lingkungan, dimana perempuan lebih banyak mencari dukungan dan perlindungan dari orang lain untuk meregulasi emosi mereka, sedangkan anak laki-laki menggunakan latihan fisik untuk meregulasi emosinya. Faktor jenis kelamin ini memengaruhi tingkat regulasi emosi seseorang.

Salah satu faktor yang dipercaya dapat memengaruhi proses fisiologis adalah budaya yang dimiliki oleh individu. Menurut hasil penelitian Ekman (dalam Dayakisni dan Yuniardi, 2004, h.93) bahwa terdapat perbedaan penerimaan dan kontrol emosi dari beberapa budaya. Keberagaman budaya membawa manusia untuk dapat beradaptasi, menerima perbedaan, membangun hubungan yang luas dan mengatasi konflik yang berakar pada perbedaan budaya. Dengan kata lain, perbedaan budaya memiliki peranan penting untuk mengetahui cara seseorang meregulasi emosinya.

Beberapa penelitian yang memiliki kaitan dengan regulasi emosi di Indonesia diantaranya, penelitian yang 
dilakukan oleh Alfian (2014, h. 271-273) kaitannya dengan regulasi emosi pada mahasiswa menunjukan ada perbedaan yang signifikan regulasi emosi antara mahasiswa suku Banjar, mahasiswa suku Jawa dan mahasiswa suku Bima. Adapun penelitian lain oleh Natalia $(2015$, h. 5163) menyatakan bahwa regulasi emosi pada mahasiswa suku Jawa terbukti lebih tinggi dibanding mahasiswa suku Karo.

Dalam teori psikologi perkembangan mahasiswa berada pada kelompok dewasa awal. Peneliti memfokuskan mahasiswa baru karena peneliti melihat banyak mahasiswa baru menghadapi berbagai tantangan. Selain itu mahasiswa baru juga menghadapi tekanan akibat proses akulturasi budaya baru di tempat menuntut ilmu. Mahasiswa menghadapi perubahan budaya, perubahan gaya hidup, perubahan lingkungan dan mahasiswa dituntut mampu menyesuaikan diri dan mengatasinya dengan baik.

Mahasiswa suku Batak yang datang dari provinsi Sumatera Utara dan yang sekarang berada di kota Semarang adalah suku pendatang yang akan bertemu dengan budaya yang berbeda. Berbagai permasalahan dapat muncul akibat proses penyesuaian diri. Suku Batak memiliki steorotip dengan budaya yang keras dan tegas sedangkan hal tersebut sangat berbeda dengan budaya Jawa yang memiliki budaya yang lembut. Mahasiswa suku Batak perlu memahami dan menghargai kebudayaan seperti nilai-nilai, kebiasaan, bahasa, tradisi masyarakat yang dianut masyarakat setempat.

Mahasiswa dari suku Jawa yang menetap di kota Semarang dan sekitarnya akan bertemu orang-orang yang berasal dari budaya yang berbeda. Mahasiswa suku Jawa belajar dan melihat pengalaman dari perilaku orang lain serta menerima perubahan ketika menjalin interaksi dengan suku yang lain (memberikan respon yang baik dan sikap saling terbuka mau menerima), terkhusus dengan kedatangan suku Batak di Semarang.

Berbagai kondisi dan situasi yang penuh tantangan tersebut menyebabkan mahasiswa membutuhkan regulasi emosi agar mampu menyesuaikan diri dan mengembangkan diri dengan baik. Bagaimana mahasiswa dapat melakukan penyeimbangan keadaannya di lingkungan dari segala perubahan yang terjadi baik sikap, perilaku atau perasaan.

Di Indonesia sering terdengar stereotip-stereotip kesukuan yang menunjukan karakteristik tertentu dalam proses interaksi sosial. Suku yang sangat dikenal oleh kebanyakan orang Indonesia adalah suku Jawa dan suku Batak.

Dalam sebuah kelompok budaya, misalnya orang Jawa beranggapan bahwa mereka halus dan sopan, dan orangorang Batak kasar dan nekat. Orang Batak mengganggap Jawa lebih halus dan spontan, namun lemah dan tidak suka berterus terang. Apa yang orang Jawa anggap kekasaran, bagi orang Batak hal itu justru suatu kejujuran. Prasangka kesukuan ini, menunjukan bahwa perbedaan kultur dalam proses komunikasi dan interaksi sosial yang melibatkan emosi rentan sekali dengan kesalahpahaman.

Konflik yang tidak sekedar menuntut pemecahan melainkan lebih pada pemahaman dan kesadaran akan keberagaman budaya yang membawa pada kemampuan beradaptasi, menerima perbedaan, membangun hubungan yang luas, dan mengatasi konflik yang berakar pada perbedaan budaya. Perbedaan yang mencolok antara budaya Jawa dengan budaya Batak menjadi faktor yang harus 
diperhatikan karena memengaruhi gaya dari masing-masing pihak.

Berdasarkan pemaparan dari latar belakang masalah diatas, maka menimbulkan pertanyaan apakah ada perbedaan regulasi emosi dan jenis kelamin pada mahasiswa bersuku Batak dan mahasiswa bersuku Jawa yang sedang menempuh pendidikan Perguruan Tinggi? sehingga penulis melakukan penelitian tentang "Perbedaan regulasi emosi dan jenis kelamin pada mahasiswa bersuku Batak dan mahasiswa bersuku Jawa". Hipotesis yang disampaikan dalam penelitian ini adalah : (1) Ada perbedaan regulasi emosi antara mahasiswa yang bersuku Batak dan mahasiswa yang bersuku Jawa. Mahasiswa yang bersuku Jawa memiliki tingkat regulasi emosi lebih baik daripada mahasiswa yang bersuku Batak; (2) Ada perbedaan regulasi emosi pada perempuan dan laki-laki. Perempuan memiliki regulasi emosi lebih tinggi dibandingkan dengan laki-laki.

\section{METODE}

Penelitian ini melibatkan tiga variabel, yaitu Regulasi Emosi sebagai variabel tergantung dan Suku Bangsa (Batak dan Jawa) serta Jenis kelamin (laki-laki dan perempuan) sebagai variabel bebasnya. Populasi penelitian adalah mahasiswa angkatan 2016 Universitas Dipenegoro Semarang yang berasal dari etnis Batak (berasal dari provinsi Sumatera Utara) dan etnis Jawa (berasal dari kota Semarang dan sekitarnya) serta duduk di semester dua. Teknik pengambilan sampel yang digunakan adalah accidental quota sampling dengan kriteria yaitu minimal 18 tahun, mampu menggunakan Bahasa dari suku yang dimiliki, memiliki orangtua yang keduanya memiliki suku yang sama. Quota yang ditetapkan adalah
120 orang (masing-masing suku berjumlah 60 orang)

Pengumpulan data yang digunakan dalam penelitian ini menggunakan metode skala, yaitu Skala Regulasi Emosi yang disusun berdasarkan aspek yang terdiri dari pemilihan situasi, modifikasi situasi, penyebaran perhatian, perubahan kognitif, modifikasi respon, memonitor emosi, mengevaluasi emosi dan memodifikasi emosi. Setiap pernyataan diberikan empat alternatif jawaban. Empat kategori jawaban tersebut yaitu Sangat Sesuai (SS), Sesuai (S), Tidak Sesuai (TS), Sangat Tidak Sesuai (STS). Untuk item favorable akan diberikan skor tertinggi 4 untuk jawaban Sangat Sesuai (SS), skor 3 untuk jawaban Sesuai (S), skor 2 untuk jawaban Tidak Sesuai (TS) dan skor 1 untuk jawaban Sangat Tidak Sesuai (STS). Untuk item unfavorable diberikan skor sebaliknya, skor 4 diberikan untuk jawaban Sangat Tidak Sesuai (STS), skor 3 untuk jawaban Tidak Sesuai (TS), skor 2 untuk jawaban Sesuai (S), dan skor 1 untuk jawaban Sangat Sesuai (SS).

Validitas pada penelitian ini menggunakan validitas isi dan konstruk. Validitas isi (Azwar, 2015, h. 112), yaitu validitas yang melihat alat ukur dapat dievaluasi melalui nalar dan akal sehat serta kesepakatan dengan penilai yang kompeten (expert judgement). Dalam penelitian ini yang menjadi expert judgement adalah dosen pembimbing skripsi peneliti dan empat orang mahasiswa psikologi.

Validitas konstruk (Azwar, 2015, h. 116) adalah hasil pengukuran yang diperoleh melalui item-item tes berkorelasi tinggi dengan konstrak teoritik yang mendasari penyusunan tes tersebut. Validitas konstruk dengan 
kualitas item yang memiliki kriteria batasan $r_{i x} \geq 0,30$.

Reliabilitas adalah konsistensi atau stabilitas yang ada pada prinsipnya menunjukan sejauh mana pengukuran tersebut dapat memberikan hasil yang relatif tidak berbeda bila dilakukan pengukuran kembali terhadap subyek yang sama (Azwar, 2016). Pengujian item-item pada penelitian ini menggunakan koefisien Alpha Cronbbach yang dihitung melalui SPSS.

Metode analisis data pada penelitian ini menggunakan t-test, uji analisis Independent Samples Test untuk perbedaan regulasi emosi dan jenis kelamin pada mahasiswa yang bersuku Batak dan mahasiswa yang bersuku Jawa. Perhitungan analisis digunakan bantuan menggunakan komputer pada program SPSS, untuk mengetahui tinggi dan rendah berdasarkan regulasi emosi dan jenis kelamin.

\section{HASIL PENELITIAN}

Hasil uji normalitas pada regulasi emosi suku Batak menggunakan teknik One-Sample Kolmogrov-Smirnov Test menunjukan nilai nilai $\mathrm{p}=0,846$ $(\mathrm{p}>0,05)$ dan suku Jawa dengan nilai $\mathrm{p}=$ $0,329(p>0,05)$. Berdasarkan hasil uji asumsi yang telah dilakukan, menunjukan bahwa regulasi emosi pada suku Batak dan suku Jawa memiliki sebaran data yang normal.

Hasil perhitungan uji homogenitas regulasi emosi pada suku Batak dan suku Jawa dengan menggunakan teknik Levene's Test menunjukan nilai $\mathrm{p}=0,05(\mathrm{p} \geq 0,05)$ ini menunjukan bahwa sebaran data dikatakan homogen.

Hasil $t$-test yang menguji regulasi emosi pada mahasiswa suku Batak dengan mahasiswa suku Jawa menghasilkan nilai $t_{0}$ sebesar -2.355 dengan $\mathrm{p}=0,010 \quad(\mathrm{p}<0,05)$ yang menyatakan ada perbedaan regulasi emosi yang signifikan antara mahasiswa suku Batak dengan mahasiswa suku Jawa di Universitas Dipenegoro Semarang. Hasil rerata regulasi emosi pada mahasiswa suku Jawa dengan nilai (Mean=86,50) sedangkan pada suku Batak sebesar (Mean=83,48). Hal ini menunjukan bahwa regulasi emosi pada mahasiswa suku Jawa lebih tinggi dibandingkan mahasiswa suku Batak.

Dalam menguji data untuk melihat perbedaan regulasi emosi berdasarkan jenis kelamin (laki-laki dan perempuan), dianalisis menggunakan Independent Samples Test. Hasil data yang diperoleh berdasarkan jenis kelamin pada kedua kelompok suku memiliki $\mathrm{t}_{\mathrm{o}}=0,008$ dengan $p=0,497(p>0,05)$ yang berarti tidak ada perbedaan regulasi emosi antara laki-laki dan perempuan.

Dalam menguji data untuk melihat perbedaan tingkat regulasi emosi berdasarkan aspek-aspek regulasi emosi dianalisis menggunakan Independent Samples Test. Diketahui bahwa nilai $(p>0,05)$ yaitu seleksi situasi $(0,85)$, modifikasi situasi $(0,703)$, perubahan kognitif $(0,106)$, memonitor emosi (0,621), dan modifikasi emosi $(0,267)$. Hal ini menyatakan bahwa tidak terdapat perbedaan regulasi emosi yang signifikan pada kelima aspek tersebut. Sedangkan pada tiga aspek lainnya, nilai $(\mathrm{p}<0,05)$ yaitu penyebaran perhatian $(0,025)$, modifikasi respon $(0,010)$ dan mengevaluasi emosi $(0,004)$. Dari pernyataan tersebut, maka terdapat perbedaan yang signifikan pada kedua kelompok suku pada aspek regulasi emosi.

\section{DISKUSI}

Hasil uji hipotesis yang digunakan dengan teknik Independent 
Sample Test menunjukan nilai $\mathrm{p}=0,010$ $(\mathrm{p}<0,05)$ yang berarti ada perbedaan regulasi emosi yang signifikan antara mahasiswa suku Batak dengan mahasiswa suku Jawa. Jadi dengan demikian hipotesis diterima. Hal ini menunjukan bahwa rerata mahasiswa yang bersuku Jawa lebih baik $(M=86,50)$ daripada mahasiswa yang bersuku Batak $(\mathrm{M}=83,48)$ juga terbukti.

Hal ini terbukti karena suku Jawa diajarkan untuk bersikap pada prinsip rukun dan hormat (Suseno, 1984). Bersikap rukun yang berarti bertindak untuk berusaha menghindari konflik atau tidak menimbulkan konflik dalam pergaulan. Suku jawa membawa diri dengan sopan seperti cara bicara serta pembawaan diri dengan menunjukan sikap hormat pada orang lain. Emosi yang tidak diekspresikan menjadi cara yang sangat ditekankan pada masyarakat suku Jawa. Dasar utama sabar, nrima, ikhlas juga menjadi bagian dalam regulasi emosi sehingga regulasi emosi telah diajarkan dalam budaya Jawa.

Prinsip pada suku Batak yaitu mengutamakan harga diri serta sifat pemarah, pendendam, dan mudah tersinggung (Tinambunan, 2010). Keadaan ini memengaruhi cara bersosial yang kurang adaptif sehingga menunjukan kurang mampu meregulasi dengan baik. Kehidupan masyarakat Batak yang mengutamakan harga diri cenderung terfokus pada diri sendiri, keluarga, atau kerabat disekitar mereka. Jika ada orang asing yang mengganggu atau melakukan hal buruk, maka orang Batak cenderung langsung menyerang dengan emosi. Hal ini yang membuat orang Batak memiliki regulasi emosi yang rendah.

Hasil yang diperoleh berdasarkan jenis kelamin dikatakan bahwa tidak ada perbedaan regulasi emosi antara laki-laki dan perempuan, menunjukan nilai $\mathrm{p}=$ 0,497 ( $>00,05)$. Jadi dengan demikian hipotesis ditolak. Hal ini dapat ditarik bahwa regulasi emosi pada jenis kelamin bukan faktor determinan dari emosi. Ada indikasi bahwa emosi dan regulasi emosi merupakan kecenderungan yang dibentuk oleh pola asuh, sosialisasi dan budaya (dalam Ratnasari \& Suleeman, 2017).

Pada ketiga aspek yang terdapat perbedaan karena pada suku Jawa cenderung memiliki regulasi emosi pada aspek penyebaran perhatian yang tinggi karena pengajaran suku Jawa untuk mengembangkan norma-norma kelakuan sehingga dapat mencegah terjadinya emosi yang menimbulkan suatu konflik. Hal ini juga menjadi cara pandang dasar bagi suku Jawa yang diajarkan untuk sabar dari segala keadaan yang terjadi. Sedangkan pada suku Batak, memiliki rerata cenderung rendah karena pada orang Batak lebih mengekspresikan setiap emosinya sehingga tidak membuat orang Batak memendam emosinya.

Mahasiswa Jawa pada aspek modifikasi respon juga memiliki rerata lebih tinggi karena dasar utama untuk nrima dalam arti sikap hidup yang positif terhadap perilaku orang lain. Hal ini membuat orang Jawa mampu mengubah respon dengan baik. Sementara itu, pada orang Batak pada aspek modifikasi respon cenderung rendah karena orang Batak memiliki sifat kritis dan tegas dalam bertindak dan menghadapi masalah. Jadi hal ini membuat orang Batak tidak berfikir konsekuensinya.

Pada aspek mengevaluasi emosi, mahasiswa Jawa juga memiliki rerata lebih tinggi karena dasarnya orang Jawa menghindari adanya perselisihan sehingga membuat setiap individu orang Jawa tidak terbawa dan terpengaruh pada emosi yang mendalam. Lain halnya 
dengan orang Batak, memiliki rerata lebih rendah karena sifat orang Batak yang mudah tersinggung ketika dirinya diceritakan secara negatif apalagi belum terselesaikan dengan baik.

Pada aspek seleksi situasi, mahasiswa Jawa dan mahasiswa Batak memiliki rerata dengan nilai yaitu 6,78 suku Jawa dan 6,53 suku Batak. Dari kedua kelompok tidak ada perbedaan, karena budaya Jawa mengajarkan untuk menghindari masalah (Suseno, 1984). Hal ini diduga mahasiswa yang bersuku Jawa mampu menghindari masalah dan mampu memilah sumber masalah yang harus dihadapi. Pada budaya Batak, orang Batak ketika perantauan jauh mampu menempatkan diri dalam masyarakat. Keadaan ini membuat orang Batak belajar dari pengalaman ketika bersosialisasi. Dalam hal ini orang Jawa dan orang Batak dikatakan mampu seleksi situasi dengan baik.

Pada aspek modifikasi situasi juga, kedua kelompok memiliki rerata sebesar yaitu suku Jawa dengan nilai 9,02 dan suku Batak dengan nilai 8,93. Hal ini terjadi karena suku Jawa mampu berbahasa dengan halus dalam menyampaikan keinginan dan suku Jawa menggunakan prinsip hormat untuk mencegah terjadinya ketegangan dalam berkomunikasi (Suseno, 1984). Pada suku Batak, saat berbicara dengan orang lain cukup demokratis dan memiliki sikap menghargai dengan memberikan kesempatan pada lawan bicara. Hal ini yang membuat orang Jawa dan orang Batak dikatakan mampu modifikasi situasi dengan baik.

Pada perubahan kognitif, kedua kelompok memiliki rerata sebesar 15,40 pada suku Jawa dan 14,87 pada suku Batak. Hal ini terjadi pada suku Jawa yang terfokus pada kesejahteraan orang lain tanpa terfokus pada emosi yang dimilikinya. Sedangkan pada suku Batak dalam berbicara apa yang menjadi pemikirannya cenderung dikomunikasikan pada lawan bicaranya. Hal ini membuat orang Jawa dan orang Batak mampu mengubah kognitif dengan cara yang baik. Pada aspek memonitor emosi, suku Jawa memiliki rerata sebesar 8,47 dan suku Batak sebesar 8,57. Dari nilai yang diperoleh, terjadi karena pada suku Jawa setiap individunya dituntut untuk selalu mawas diri dan menguasai emosemosi. Perasaan yang tidak enak yang muncul apalagi menimbulkan pertentangan, masyarakat Jawa dituntut agar selalu dapat mengontrol dirinya. Sedangkan orang Batak, emosi yang dirasakan cenderung disampaikan secara langsung dan terbuka baik pada lawan bicara ketika ada sesuatu yang kurang berkenan. Kemudian hal ini membuat orang Jawa dan orang Batak sudah mampu memonitor emosi dengan baik.

Terakhir pada aspek modifikasi emosi, kedua kelompok memiliki rerata sebesar 12,87 pada suku Jawa dan 12,55 pada suku Batak. Hal ini terjadi karena suku Jawa diajarkan dalam teknik ethokethok dimana untuk menghindari kekecewaan dengan kebiasaan berpurapura. Teknik ini berlaku dalam perasaanperasaan yang negatif, ketika individu diliputi sedih yang mendalam, diharapkan tetap tersenyum. Lain halnya dengan orang Batak, yang memiliki sifat percaya diri dan berpendirian teguh dalam falsafah Batak "Hasangapon". Orang Batak berusaha menjadi orang yang terpandang dan di hormati dalam masyarakat sehingga masalah bukan tantangan tetapi kesempatan untuk memperbaiki (Tinambunan, 2010). Hal ini yang membuat orang Jawa dan orang Batak mampu memodifikasi emosi dengan baik. 


\section{SIMPULAN}

Berdasarkan hasil penelitian yang dilakukan maka dapat disimpulkan bahwa adanya perbedaan regulasi emosi pada mahasiswa yang bersuku Batak dan bersuku Jawa. Tingkat regulasi emosi mahasiswa yang bersuku Jawa lebih baik daripada mahasiswa yang bersuku Batak. Pada analisis jenis kelamin secara keseluruhan dalam penelitian ini menyatakan tidak ada perbedaan regulasi emosi antara perempuan dan laki-laki, artinya regulasi emosi perempuan tidak lebih tinggi dibandingkan laki-laki.

Saran :

Berdasarkan penelitian dari hasil pembahasan, maka peneliti memberikan beberapa saran sebagai berikut : (1) Bagi peneliti selanjutnya ketika melakukan penelitian pada suku tertentu, disarankan untuk lebih mendalami karakter sifat budaya secara umum, peran budaya dan nilai-nilai yang berkontribusi pada regulasi emosi seseorang. Kemudian jumlah subyek penelitian ditambah dan proporsi subyek laki-laki maupun perempuan seimbang agar lebih mudah untuk dibandingkan. (2) Bagi yang bersuku Jawa dan bersuku Batak, pada aspek yang diterima diharapkan mahasiswa tetap mempertahankan dan meningkatkan kecakapan dalam regulasi emosi untuk menjadi bekal dalam menghadapi situasi sosial agar semakin baik.

Bagi yang bersuku Jawa dan bersuku Batak, pada aspek yang ditolak diharapkan mahasiswa lebih meningkatkan dan dapat melatih lebih banyak lagi sehingga kecakapan regulasi emosi lebih baik lagi dalam berhubungan sosial.

\section{DAFTAR PUSTAKA}

Alfian, M. 2014. Regulasi Emosi pada Mahasiswa Suku Jawa, Suku Banjar dan Suku Bima. Jurnal Ilmiah Psikologi Terapan. Vol. 02. No. 02 (263-275).

\section{Azwar, S. 2015. Reliabilitas dan} Validitas Edisi 4. Yogya-karta: Pustaka Pelajar. - 2016. Metode Peneli-tian. Yogyakarta: Pustaka Pelajar.

Dayakisni, T., \& Yuniardi, S. 2004. Psikologi Lintas Bu-daya. Malang: Universitas Muhammadiyah.

Gross, J.J. 2007. Handbook of

Emotion Regulation. New York: The Guilford Press.

Natalia, A. 2015. Perbedaan Regulasi Emosi pada Mahasiswa yang Bersuku Karo dan Bersuku Jawa. Skripsi. Yogyakarta: Fakul-tas Psikologi Universitas Sanata Dharma.

Nisfiannoor, M., \& Kartika Y. 2004. Hubungan antara Regulasi Emosi dan Penerimaan Kelompok Teman Sebaya pada Remaja. Jurnal Psikologi. Vol. 2. No. 2 (160-177).

\section{--------. 2006. Seorang Bapak Tega Setrika Anak Kandungnya. www.suaramerdeka.com}
Ratnasari, S., \& Suleeman, J. 2017. Perbedaan Regulasi Emosi Perempuan dan Laki-Laki di


Perguruan Tinggi. Jurnal Psikologi Sosial. Vol. 15. No. 01 (35-46).

Rifauddin, M. 2016. Fenomena Cyberbullying pada Remaja.

Jurnal Ilmu Perpustakaan, Informasi, dan Kearsipan Khizanah Al-Hikmah. Vol 4. No. 1 (35-44).

Suseno, F.M. 1985. Etika Jawa. Jakarta: PT Gramedia.

Tinambunan, D. 2010. Orang Batak Kasar? Membangun Citra \& Karakter. Jakarta: PT Elex Media Komputindo. 